\title{
Demonstrating value in the return on capital employed in information services
}

\author{
O. Garratt
}

Fairbridge Arderne and Lawton Incorporated

info@fairbridge.co.za

\section{Adeline du Toit}

Department of Information Studies

RAU University

asadt@lw.rau.ac.za

\section{Contents}

1. Introduction

2. Return on capital employed (ROCE)

3. Development of procedures to measure ROCE in a corporate information service

4. Findings of the cost-recovery feasibility exercise

5. Discussion

6. Conclusion

7. References

\section{Introduction}

In the past, information services were typically created to further the operational objectives of a parent organization. The continued existence of corporate information services was seen to be subject to management perceptions of value of its services. It was acknowledged that organization information services existed to further the mission and goals of the parent company (St Clair 1998:104). In due time, however, it appeared that decision-makers in organizations that re-engineered their support services required more than concrete demonstration of the value of services to the parent company. The closure of a branch library in an American law firm in 1995 shocked and discomforted information professionals. A business decision to outsource various support services that was made in the light of strategic and operational objectives of the parent organization showed no apparent regard for the value of the information services to the practitioners in the relevant law office (Pergament 1999).

This article is a report on an experiment to determine whether cost recovery and potential generation of profit were appropriate measures of the value of corporate information services in a law firm. 


\section{Return on capital employed (ROCE)}

\subsection{Concepts: return on investment and return on capital employed}

In the language of management accounting, return on investment (ROI) is regarded as a precise financial measure relating to the dividend that an investor could expect on an investment (Who owns whom 1988:96). ROI is an expression often encountered in business literature. The over-use of this expression in the popular management press in the late 1990s obscured the precise meaning of the term as an expression of financial return and the authors of this article prefer to use the alternative expression, return on capital employed (ROCE). The term ROCE is the measure used to describe the financial dimension in the balanced scorecard (Kaplan and Norton 1992:72).

\subsection{Distinction between 'investment' and 'capital employed'}

Determination of the financial value of an investment is complicated by the recognition that organizations calculate investment in different ways (Faul et al. 1997:540) and that there is no general acceptance of what constituted the investment value of corporate information. Information costs in a law firm are typically expensed in the income statement in the year in which they are incurred (Dyke 2001). From an accounting perspective this means that in effect the information assets at the beginning of each new financial year are valued at zero. This is not a perception shared by information users, for whom the legacy information resources are extremely valuable. In instances where ROI is documented in information literature, it is clearly the legacy resources and not the resources acquired during the year of account that are yielding a return.

This ambivalence in interpretation of investment value with regard to information services is important in considering the use of ROI or ROCE as a basis for demonstration of value. Accounting practices that evaluate ROCE in a financial year are not the same as those that evaluate a legacy resource.

It was not the intention in this research study to evaluate the merits of ROI or ROCE. The investigation of cost recovery proceeded from the recognition that in order to justify the existence of corporate support services there had to be demonstrable accountability for expenditure.

\subsection{ROCE as an element of output}

ROCE is understood to centre on the relationship between income produced by an activity and the monetary investment in that activity (Cram 1995). Cooper (1999:5) describes this in terms of output which the customer received and for which he/she was willing to pay.

In the manufacturing and retail value chain, sales validate output. In a service environment it is important that the point of sale be similarly identified in order to validate service output. In information services it is proposed that the point of sale occurs when a transaction satisfies a customer's information requirement and can conceptually be billed to a client or passed on as a notional charge. A notional charge is understood to indicate how much money could have change hands had the transaction been carried out in the open market (Dyke 2001).

\subsection{Claims for ROCE in information services}

Griffiths and King (1993:28) suggest that information services provided by so-called special libraries enhance practitioner performance in three operational areas: increased productivity, enhanced performance of work and quality, and improved speed. Griffiths and King make 
impressive claims for the cost effectiveness of corporate information services. Their calculations include the presumption that it would cost on average 2,9 times more for (specific) practitioners to obtain information from sources other that from a corporate information service (Griffiths and King 1993:27). The provision of corporate information services to practitioners in their view represents therefore an effective rate of at least $100 \%$, higher when the waste of practitioner time is included in the calculations (Griffiths and King 1993:27).

Cram (1995; 2001) claims an average return ratio of eight to one when the Corporate Library in Education, Queensland, Australia used a methodology to measure performance at the point of transaction of every reference and research question.

Other anecdotal evidence, while strongly in support of the positive benefit of the corporate investment, is more cautious in its determination of monetary return. Factiva, a Dow Jones and Reuters company developed a survey questionnaire in 1998 that attempted to evaluate the return on investment when a practitioner subscriber made use of its online product, Dow Jones Interactive. The questionnaire attempted to plot patterns of use with regard to frequency and duration of searches (Sykes 1999). It also tried to determine return on investment with reference to savings in time, elimination of duplication, response to competitive threats, improved customer focus and improved decision making. The Factiva survey provided anecdotal evidence of customer satisfaction with the service. It also, however, recognized the limitations with regard to assigning a precise monetary value to information or to the information service (Sykes 1999).

Cram (2001) notes that the value of information to a user is determined by his/her requirements and by hisher capacity to make use of the information. Value theories of supply and demand are pertinent to the determination of value of information services, but they were disregarded in this study of cost recovered. The study described below limited its scope to the identification of those operational activities where labour costs in the provision of certain services could be recovered.

\subsection{Labour costs and billable hours}

In this study, the investment in labour was shown to represent a significant percentage of capital employed in the maintenance of corporate information services. Legal practitioners typically bill their clients by time and in a law practice it is common for practitioners to have a target of billable time in the order of 5,5 hours per day or 1100 hours per year (Faris 2001:21). Faris recommends that professional and support staff should also have targets of billable time.

'As the salary cost in a law firm is the single largest expense, the failure to include a charge for time spent by professional and support staff will materially erode the practitioner's own hourly rate charge and substantially reduce profits' (Faris 2001:21).

It appeared from the collegial communication on listservs that many information professionals in the United States of America are expected to log billable hours for their professional services. There is no evidence to suggest that information specialists working in law firms in South Africa are required to account for billable hours. The study related below was a feasibility study that was designed to test whether there was merit in recording billable hours.

\section{Development of procedures to measure ROCE in a corporate information service}




\subsection{Rationale for the study}

The researchers developed a procedure to measure value of the corporate investment in information services by demonstrating potential return on the capital employed during the course of the financial year. This was both an exercise to justify the existence of the information service in the organization and also an attempt to account for the labour costs and their allocation. The cost recovery exercise investigated the merit of cost recovery as a measure of value of corporate information services.

\subsection{Assumptions}

- Where information services could be costed they could be assigned a cost recovery figure. An exercise of this nature provided also for recovery of development costs.

- Amounts could be charged to individuals or to specific departments with regard to the cost of labour in providing the service.

- The cost of general information service support operations could be recovered by levying a charge on information users on a pro-rata basis.

- A fee could be charged for the fulfilment of a special request from a practitioner on behalf of a client. The option of billing the client would, however, rest with the practitioner.

- Charges could be levied at variable rates.

\subsection{Motivation for variable costs}

Operational activities that maintain the information resources required by practitioners are sometimes known as housekeeping activities. These routine activities make provision for the acquisition, organization and maintenance of information resources and services for the information users. Certain housekeeping services are outsourced to professional support organizations or to independent contractors in order to free the information professional for client-based services such as research, current awareness and practitioner training. The housekeeping services most frequently outsourced are maintenance of the collection of loose-leaf publications and physical annotation of law reports. Seventy five per cent of respondents in the OSALL Salary Survey (2000) worked in law firms where loose-leaf updating were outsourced to independent contractors. The corresponding percentages relating to outsourcing the annotation of law reports and statutes were $43 \%$ and $21 \%$ respectively (OSALL 2000).

Notwithstanding warnings against distinguishing between high- and low-value services (Cram 1995), it was proposed in this feasibility study that the rate of cost recovery on different types of services might be variable. The evidence that independent consultants charged variable fees for outsourced services supported this decision. In the OSALL Salary Survey (2000) independent contractors in South African law firms indicated that they applied variable rates according to the nature of the service provided.

The principle of variable rates was applied in the development of a cost recovery strategy in a Cape Town law firm. For the feasibility study the nominated rates did not correspond with the rates levied by independent consultants.

To illustrate the application of variable rates to information services the standard rate on operational activities or services was determined to be the cost of labour to perform those services. The unit cost of labour was deemed to be the cost to the organization of one minute of information professional or consultant time for performing that activity or service. Housekeeping services were billed at the standard rate. 
The designated billable rate on client-based services was three times the unit cost of labour. It was suggested that this was in line with standard business practice in professional service firms (Dyke 2001). It also made provision for the recovery of costs incurred in the development of products and services that could not be charged to any other account.

\subsection{Calculation of notional cost recovery}

A spreadsheet record was created as an adjunct to the time log in order to calculate billable time, where billable time was understood to be that part of professional time that could be charged to a client account, a user account or a departmental account. The time logged in respect of information services was captured either as a standard or a premium service. The formulae that were applied to these fields automatically calculated subtotals at the designated cost recovery rates. These were notional charges and the results corresponded to potential income for various activities. When the totals were compared with the cost to the law firm of providing serviced information facilities it was theoretically possible to establish a ROCE with regard to the provision of information services.

\section{Findings of the cost-recovery feasibility exercise}

The study was conducted from January to June 2001. Total billable time was calculated as a percentage of the minutes available. For the purposes of this study minutes available were determined as 400 minutes per working day. The results are tabulated in Table 1.

Table 1 Billable time as percentages of minutes available: January-June 2001

\begin{tabular}{|l|c|c|c|}
\hline & Total billable time & Standard services & Premium services \\
\hline January & $52 \%$ & $24 \%$ & $28 \%$ \\
\hline February & $66 \%$ & $22 \%$ & $44 \%$ \\
\hline March & $67 \%$ & $23 \%$ & $44 \%$ \\
\hline April & $53 \%$ & $14 \%$ & $39 \%$ \\
\hline May & $61 \%$ & $14 \%$ & $47 \%$ \\
\hline June & $63 \%$ & $21 \%$ & $42 \%$ \\
\hline
\end{tabular}

Standard services were determined to be information service housekeeping activities and premium services were client-based services that included research, current awareness and practitioner training. Professional development and evaluation, new product development, and personal matters could not be billed to an account.

Total billable time for the period January to June 2001 ranged from 51\% to 65\%. The lowest figure relating to billable time was recorded in January 2001, and this low reading was attributed to seasonal fluctuation. The percentage of time devoted to client-based services was particularly low in relation to data for the other months.

The rates in respect of standard and premium services were embedded as formulas in the spreadsheet record. The rate for standard services for this feasibility study was nominated as the actual cost of labour, the premium rate was nominated as three times the actual cost of labour. The results of these calculations indicated the notional recovered amounts in respect of standard and premium services (see Table 2).

Table 2 Notional cost recovery January-June 2001 


\begin{tabular}{|l|c|c|c|c|c|}
\hline & $\begin{array}{c}\text { Standard } \\
\text { recoverable* }\end{array}$ & $\begin{array}{c}\text { Premium } \\
\text { recoverable* }\end{array}$ & $\begin{array}{c}\text { Total } \\
\text { recoverable* }\end{array}$ & $\begin{array}{c}\text { Actual cost } \\
\text { of labour* }\end{array}$ & $\begin{array}{c}\text { Value } \\
\text { added* }\end{array}$ \\
\hline January & 1762 & 6167 & 7929 & 7850 & 79 \\
\hline February & 1699 & 10239 & 11939 & 7870 & 4089 \\
\hline March & 1686 & 9409 & 11095 & 8200 & 2895 \\
\hline April & 1143 & 9179 & 10322 & 8200 & 2122 \\
\hline May & 1034 & 10673 & 11708 & 8200 & 3508 \\
\hline June & 1640 & 9982 & 11623 & 8200 & 3423 \\
\hline
\end{tabular}

*Amount in South African rands to the nearest rand

Since the standard rate of recovery was nominated as the actual cost of labour, it was only when premium services were transacted that value was perceived to be added to corporate information services.

Premium services were identified as client-based services such as reference and research and the amount of time spent on these operational activities was very dependent on practitioner demand. January was acknowledged to be a quiet time of the year when many practitioners took leave. It was therefore also a time when billable hours were low and added value was minimal. The higher notional recoveries in subsequent months reflected more time spent on value-added services.

\section{Discussion}

The results of the feasibility study suggest that notional billing of information professional time within an organization is an effective demonstration of the value of the information services of the organization. The ratio of billable time to total time available is an indication of service utilization; over time the data will also indicate seasonal fluctuation in demand for services. The distinction between standard and premium services is perceived to be useful for determining whether standard services are being fulfilled at the expense of premium services. It is suggested that this may indicate the merit of outsourcing certain standard services in order to concentrate on premium services. The maintenance of operational data is seen to be critical in any decisions that may be required with regard to outsourcing operational activities.

The figures of this research suggest that corporate information services are potentially profitable if the notional charges are to be converted to actual monetary levies. The views of colleagues on the subject were less reassuring. There was no evidence that information professionals in South African law firms were expected to account for billable time. There was, however, some discussion in the professional communications regarding the merits of charging when the provision of research and reference services, for example, involve the copying of copyright-protected resources.

It is standard practice in South African law firms to recover general disbursements for telephone, photocopy and fax costs. It is clearly illegal, however, to levy a charge for copying material where the effect of this service is to deprive a legitimate copyright holder of royalty fees. This is a legal and ethical issue that exceeds the scope of this feasibility study but it creates serious doubts about the merit of implementing monetary billing per se. 
an invitation posted by the authors on the SLA-LAW discussion listserv in June 2001. One information professional suggested that far from validating the existence of corporate information services, the principle of fair payment for fair use resulted in the reduction in demand for service and a consequent review of service value.

\section{Conclusion}

The methodology to record billable time as a notional charge was an effective management practice. The claims by Griffiths and King, Cram and others regarding ROCE of information resources were validated with some qualifications. The practice of billing at three times the cost for certain premium information services indicated the extent to which the information services added value to the organization and this was construed to indicate return on capital employed.

There was, however, no support for notional billing to be converted to actual cost recovery practices. It was seen that cost recovery and generation of income were not core-operating objectives of the information services in a law firm and collegial comment suggested that billing of service time to practitioners and departments might even reduce the demand for information services. There were also legal and ethical difficulties with billing for services that involved copying material that enjoyed copyright protection.

\section{References}

Cooper, C. 1999. The ABC of productivity measurement. Productivity 25(5):4-6.

Cram, J. 1995. Moving from cost center to profitable investment: managing the perception of a library's worth. Asia-Pacific Library Conference Proceedings, Volume 1. Brisbane: State Library of Queensland: 177-189. Reprinted in Australasian Public Libraries and Information Services 8(3):107-113. [Online]. Available WWW:

http://www.alia.org.au/ jcram/moving_from_cost_centre.html. (Accessed: 2000/08/14).

Cram, J. 2001. (jcram@hotkey.net.au). RE: ROI and billable time. E-mail to Olwyn Garrett (info@fairbridges.co.za).

Dyke, M. 2001. Interview conducted on March 2001. (email: mdyke@fairbridge.co.za).

Faris, V. 2001. Staff structure and billing rates. De Rebus (February):21.

Faul, M.A., Du Plessis, P.C., Van Vuuren, S.J., Niemand, A.A. and Koch, E. 1997.

Fundamentals of cost and management accounting. 3rd ed. Durban: Butterworths.

Griffiths, J.M. and King, D.W. 1993. The special libraries: increasing the information edge. Washington DC: Special Libraries Association.

Kaplan, R.S. and Norton, D.P. 1992. The Balanced scorecard - measures that drive performance. Harvard Business Review (January-February):71-79.

OSALL Salary Survey. 2000. Report of the salary survey of the Organization of South African Law Libraries, compiled by Olwyn Garrett. [Unpublished]. 
Pergament, R. 1999. Outsourcing in law firm libraries. [Online]. Available WWW:

http://www.Ilrx.com/features/outsourcing.htm. (Accessed: 2000/08/28).

St Clair, G. 1998. Special libraries. Librarianship and information work worldwide. Edited by Line, M., McKenzie, G. and Sturges, P. London: Bowker-Saur.

Sykes, J. 1999. Factiva return-on-investment survey findings; a white paper from Factiva. [Online]. Available WWW: http://www.factiva.com/inspiring/roi/roi_A4.doc. (Accessed: 2002/08/26).

Who owns whom's dictionary of stock market terms. 1988 (reissued with additions 2001). Johannesburg: PSG Online.

\section{Disclaimer}

Articles published in SAJIM are the opinions of the authors and do not necessarily reflect the opinion of the Editor, Board, Publisher, Webmaster or the Rand Afrikaans University. The user hereby waives any claim he/she/they may have or acquire against the publisher, its suppliers, licensees and sub licensees and indemnifies all said persons from any claims, lawsuits, proceedings, costs, special, incidental, consequential or indirect damages, including damages for loss of profits, loss of business or downtime arising out of or relating to the user's use of the Website. 
ISSN 1560-683X

Published by InterWord Communications for the Centre for Research in Web-based Applications, Rand Afrikaans University 